УДК 343.85:343.352:343.973

DOI https://doi.org/10.32849/2663-5313/2021.1.23

\title{
Свген Кобко,
}

канд. юрид. наук, дочент,

доцент кафедри публічного управління та адміністрування

Начіональної академії внутрішніх справ

\section{ІНСТИТУТ ВИКРИВАЧІВ ЯК ІНСТРУМЕНТ ЗАПОБІГАННЯ ТА ПРОТИДІЇ КОРУПЦІЇ В УКРАЇНI}

У статті досліджено сучасні інструменти запобігання та протидії корупиї. Наголошено, що корупиія є складним, багатовекторним явищем і таким, що охопила всі сфери функиіонування держави та місиевого самоврядування. Враховуючи сучасні українські реалії, неможливо досліджувати всебічно та грунтовно питання корупиї без вивчення інституту викривачів. Підкреслено, що для багатьох держав світу наявність інституту викривачів є одним із результативних засобів виявлення і подолання корупції та перспективних способів демократичного розвитку суспільства. Адже саме через таку форму взаємодії можливо залучити громадськість до антикорупиійної політики та ефективно співпрацювати з громадянським суспільством, забезпечуючи таким чином поступальний розвиток відкритої сучасної держави.

Зазначається, що відсутність бажаного результату після створення низки антикорупиійних органів в Україні надала ще більш чітке розуміння необхідності активного залучення приватного сектору. Тому сучасна антикорупиійна інфраструктура в Україні включає як суб'єктів державного характеру, так і різних суб'єктів з неурядового сектору. Зарубіжний досвід свідчить, що саме залучення до антикорупиійної діяльності приватних осіб є найбільш ефективним інструментом у боротьбі з корупиією.

Акцентовано, що сучасний розвиток антикорупиійного законодавства має багато позитивних здобутків, але разом із иим залишається низка проблемних питань, які мають як юридичний зміст, так і соиіально-культурний. Щодо юридичних механізмів, то існує потреба у подальшому розвитку законодавства щодо захисту прав та інтересів викривачів; соціально-культурний чинник розвитку інституту викривачів також вимагає активних дій від держави та громадських організаиій відповідного напряму діяльності. Головним вектором змін у иьому напрямі має стати усвідомленість громадян щодо їхнього можливого впливу на корупиійний стан у державі.

Ключові слова: корупція, викривач, антикорупційна політика, антикорупційне законодавство, антикорупційна інфраструктура.

Сьогодні всі держави світу перебувають у стані трансформації своїх економік, зумовленої низкою чинників. Якщо пандемія, викликана коронавірусною хворобою (COVID-19), - це ситуаційна причина світової економічної кризи, то корупція, насамперед у діяльності органів державної влади та органів місцевого самоврядування, - постійна причина того, чому, особливо в Україні, наприклад, державний бюджет регулярно недоотримує значні кошти, економіка перебуває на низькому рівні та є багато інших негативних наслідків від корупційних діянь.

Корупція $є$ складним, багатовекторним явищем і таким, що охопило всі сфери функціонування держави та місцевого самоврядування. Тому закономірним є наявність низки наукових досліджень у цій сфері, проведених, зокрема, такими вітчизняними та зарубіжними вченими, як: $Є$. Бараш, М. Бурак, О. Бусол, Ф. Галтунг, Л. Герасименко, Я. Гончарук, М. Гребенюк, О. Дрозд, 3. Загиней, В. Зарубей, В. Ільков, Л. Кемпбелл, В. Киричко, Д.-Е. Лейн, В. Ліщенко, М. Мельник, Л. Наливайко, О. Стрільцов, О. Терещук, М. Флейчук, П. Хейвуд, С. Чернявський та багато ін. Науковці вивчали питання щодо змістового наповнення поняття «корупція», причин їі виникнення, шляхів подолання тощо. Однак у сучасних українських реаліях неможливо досліджувати всебічно та грунтовно питання корупції без вивчення інституту викривачів - розкриття ролі та місця осіб, які інформують про порушення норм законодавства, у тому числі щодо корупції, у механізмі антикорупційної державної політики.

Для багатьох держав світу наявність інституту викривачів є одним із результатив- 
них засобів виявлення і подолання корупції та перспективних способів демократичного розвитку суспільства. Адже саме через таку форму взаємодії можливо залучити громадськість до антикорупційної політики та ефективно співпрацювати 3 громадянським суспільством, забезпечуючи таким чином поступальний розвиток відкритої сучасної держави.

Проблематиці інституту викривачів корупції як засобу запобігання їй та подолання поки що приділено не так багато уваги в українській правовій науці: серед авторів, які розглядали цей напрям, - В. Бенедик, М. Буроменський, В. Василинчук, В. Гвоздецький, О. Грибовський, З. Загиней, О. Костенко, О. Мезеря, О. Нестеренко, В. Плиска, О. Сердюк, Г. Татаренко, I. Татаренко, Н. Чудик, О. Шостко, І. Яцків та ін. Перспективним та провідним напрямом дослідження у цій сфері є захист прав викривачів в Україні. Так, на дисертаційному рівні проблематику правового механізму забезпечення прав викривачів з позицій адміністративного права досліджувала О. Косиця [1; 2]. Незважаючи на теоретико-прикладну значимість проведених досліджень, все ж існує значна необхідність у подальших грунтовних розвідках 3 метою ефективності функціонування інституту викривачів в Україні.

Корупція є універсальним явищем для усього світу [3, с. 102]. Ефективна протидія корупції - одна із найактуальніших проблем сучасності. 3 моменту проголошення Україною незалежності ця проблема стала предметом підвищеної уваги як українських науковців, так і політичних діячів та керівників держави. Цінною підтримкою для вирішення складних завдань боротьби з корупцією в українських реаліях став досвід інших країн і та теоретична й методологічна база, яка вже напрацьована європейськими вченими. Дослідники наголошують, що вирішення даної проблеми неможливе без системного вивчення сутнісних ознак, проявів, детермінуючих факторів цього негативного суспільного явища $[4$, с. 34]. Навряд чи можна сперечатися з таким твердженням.

У звітах авторитетних міжнародних організацій протягом багатьох років традиційно відзначається, що Україна з часу набуття незалежності перебуває під значним впливом корупції. При цьому окремо наголошується на особливому поширенні корупційних проявів у сфері дозвільної та контролюючої діяльності органів державної влади щодо підприємців, під час судового розгляду спорів та діяльності правоохоронних органів, державного адміністрування та контролю за сплатою податків і митного оформлення товарів, у сфері державних закупівель, енергетичному секторі, розподілі землі та інших природних ресурсів. Проведення виборів також характеризується, як правило, корупційними зловживаннями, підкупом виборців тощо [5]. Усе це свідчить про необхідність розвитку та впровадження нових механізмів подолання корупції.

Одна з найвідоміших у світі спеціалізованих інституцій з боротьби проти корупції Незалежна комісія проти корупції, заснована в Гонконзі у 1974 р., своєю діяльністю зробила значний внесок в успіх Гонконгу в зниженні рівня корупції. Натхненні цим успіхом багато держав у світі, у тому числі країни Східної Європи, прийняли рішення про створення власних інституцій із запобігання корупції і боротьби проти неї. Цей крок часто розглядався як єдиний можливий шлях до зниження рівня корупції, тому що наявні інституції із цим завданням не могли впоратися. Укладені останнім часом міжнародні договори вимагають від держав-учасниць створити спеціалізовані органи для боротьби і запобігання корупції. Так, Конвенція ООН проти корупції вимагає наявності двох типів антикорупційних інституцій: органу або органів, що запобігають корупції; органу, органів або осіб, які спеціалізуються на боротьбі проти корупції за допомогою правоохоронних заходів [6]. Україна не стала винятком та забезпечила утворення цілісної системи органів державної влади у цьому напрямі. Події 2013-2014 рр. сприяли посиленню законодавчої бази, а також створенню спеціалізованих органів для реалізації антикорупційної функції: Національне антикорупційне бюро, Національне агентство 3 питань запобігання корупції, Спеціалізована антикорупційна прокуратура й, нарешті, початок роботи Вищого антикорупційного суду у 2019 p.

У звіті 2018 р. за результатами опитування підприємців, експертів та населення у цілому наголошено, що в Україні створена завершена антикорупційна інфраструктура, що неодноразово визнавали міжнародні організації в межах спеціальних контрольних та моніторингових процедур. Зокрема, такі оцінки містяться у висновках ГРЕКО (Група країн проти корупції), Стамбульського протоколу, ОЕСР, Ради Свропи, спеціальних органів СС тощо [7, с. 34]. Усе вищезазначене стало важливою історичною віхою у викоріненні корупції в Україні та дало підстави вважати, що ситуація щодо рівня корупції в Україні якщо не зміниться кардинально, то хоча б помітно поліпшиться, проте світові показники рейтингу корупції в Україні свідчать про необхідність подальшого вдоскона- 
лення наявних механізмів та розвитку нових. Підтвердженням цього $є$ світовий рейтинг щодо корупції у державах світу.

Україна розпочала антикорупційну реформу з показниками CPI-2014 у 26 балів зі 100 можливих. У глобальному рейтингу країна посіла 142 місце серед 175 країн. Ухвалення антикорупційних законів наприкінці 2014 р., збільшення кількості викривачів корупції та зростання кількості публікацій на антикорупційну тематику в ЗМІ отримали позитивну оцінку міжнародних експертів. Однак у підсумку CPI-2015 України зріс до 27 - посіла 130 місце серед 168 країн. За показниками CPI-2016 - 131 місце серед 176 країн. CPI-2017 - 130 місце серед 180 країн. Зростання показника індексу СРІ на 2 бали - до 32 та 120 місце в глобальному рейтингу серед 180 країн - у 2018 р. За показниками CPI-2019 Україна отримала 30 балів - на 2 бали менше, ніж минулого року, і посіла 126 місце в глобальному рейтингу [8]. Отже, у період з 2014 по 2019 рр. індекс сприйняття корупції в Україні зріс із 26 до 30 балів; корупція продовжує залишатися однією із найскладніших проблем.

Світова практика боротьби 3 корупцією показує, що найбільш ефективним заходом протидії є своєчасна поінформованість правоохоронних органів про факти корупції. Тому законодавче закріплення інституту «викривачів корупції», які надають відповідну інформацію уповноваженим суб'єктам з протидій корупції, є доцільним для кожної держави [9, с. 129]. Особливо це актуально для української правової системи. Зважаючи на розвиток антикорупційного законодавства, все більше залучення громадськості до антикорупційної діяльності, важливим є системне та всебічне вивчення інституту викривачів, враховуючи позитивний досвід багатьох держав світу у впровадженні інституту викривачів корупції (США, Канада, Велика Британія, Нова Зеландія, Австралія, Японія, Румунія та ін.).

Сучасна антикорупційна інфраструктура в Україні включає не лише спеціалізовані антикорупційні органи, але й інші політичні та соціальні інститути, антикорупційна активність яких не лише дозволена, але й прямо передбачена у національному антикорупційному законодавстві. Такий підхід є логічним і базується на принципі необхідності об'єднання зусиль всіх інститутів для подолання корупції як суспільної проблеми, що паразитує на системних недоліках українського суспільства [7, с. 34]. Зростання кількості громадян, готових повідомляти про факти корупційних проявів, а також громадян, які заявили про факти корупції, що мали стосовно них місце, компетентним органам, $є$ одним із індикаторів ефективності реалізації проєкту Антикорупційної стратегії на 2020-2024 роки, який нині перебуває на розгляді у Верховній Раді України (проєкт готується до другого читання), а захист викривачів корупції - способом підвищення ефективності системи запобігання і протидії корупції [10]. Хоча лише у 2020 р. було офіційно введено поняття «викривач» (Закон України «Про внесення змін до закону України «Про запобігання корупції» щодо викривачів корупції»), однак таке явище, як «інститут викривачів злочинних дій та правопорушень», з'явилось в українському правовому просторі ще в середині 90-х рр. $\mathrm{XX}$ ст. та пов'язано з прийняттям Конституції України, ратифікацією Конвенції про захист прав людини і основоположних свобод, а також подальшим розвитком законодавства (Закони України «Про забезпечення безпеки осіб, які беруть участь у кримінальному судочинстві» від 1994 р., «Про доступ до публічної інформації» від 2011 р., «Про засади запобігання та протидії корупції» від 2009 р., «Про засади запобігання і протидії корупції» від 2011 р. (два останніх акта втратили чинність), «Про запобігання корупції» від 2014 р. та ін.).

Додатковим чинником у необхідності розвитку інституту викривачів стало набрання чинності у 2017 р. Угодою про асоціацію України з Свропейським Союзом, Європейським Співтовариством 3 атомної енергії та їх державами-членами [11], адже однією із умов У годи стала боротьба з корупцією та 3 різними формами транснаціональної організованої злочинності й тероризмом. Сьогодні частиною національного законодавства щодо викривачів корупції є також міжнародні договори: Конвенція $\mathrm{OOH}$ проти корупції, Кримінальна конвенція про боротьбу з корупцією, Цивільна конвенція про боротьбу з корупцією тощо.

Багато країн узяли на себе зобов'язання у межах реалізації вимог міжнародних конвенцій увести в дію закони про захист інформаторів. Дедалі більше урядів, корпорацій i некомерційних організацій визначають процедури повідомлення та захисту для інформаторів. Така політика сприяє наявності доступних каналів для інформаторів, захищає їх від усіх форм помсти, гарантуючи, що інформація, яку вони надають, може бути використана для проведення необхідних реформ у країні [12, с. 227]. Безумовним лідером щодо кількості викривачів, а отже, першою країною у світі, яка ухвалила закони у сфері їх захисту, є США. Викриття 1966 р. i 1978 р. у США створили позитивний образ 
викривачів, а також спричинили сильний резонанс у суспільстві, який змусив Конгрес почати реформи у сфері державного управління, зокрема розпочати створення правових гарантій для викривачів. Ідеться про справу офіцера поліції Нью-Йорка Ф. Серпико, який виступив із показаннями щодо випадків корупції, а також про загальновідомий Вотергейтський скандал [14, с. 107 15, с. 143]. Хоча українська влада протягом багатьох років системно працює у цьому напрямі, постійно вдосконалює антикорупційне законодавство, але у зв'язку з прийняттям Закону України «Про внесення змін до Закону України «Про запобігання корупції» щодо викривачів корупції від 17.10.2019 р. дискусійність цієї проблематики стала лише актуальнішою. Оскільки, з одного боку, вдосконалення законодавства у врегулюванні правового інституту викривачів корупції (передбачено винагороду для викривачів, розширено перелік заходів захисту прав викривачів, регламентовано можливі канали інформування про корупцію та ін.) - позитивний крок, з іншого - з'явились нові або ж залишились раніше не вирішені проблеми.

Серед невирішених проблем вчені називають такі. У попередньому законодавстві особою, яка надає допомогу у запобіганні та протидії корупції вважалася особа, яка повідомила про порушення антикорупційного законодавства іншою особою. Тому у кримінальному провадженні лише заявник міг отримати статус особи, яка надає допомогу в запобіганні та протидії корупції, а отже, й отримати державний захист. Зміни, внесені Законом «Про внесення змін до Закону України «Про запобігання корупції» щодо викривачів корупції», навпаки, закарбували зазначену проблему в п. 25 ч. 1 ст. 3 Кримінального процесуального кодексу, яка тепер прямо відносить викривачів корупції до категорії заявників. Але такий підхід є вкрай помилковим, адже за змістом викривач - це той, хто надає інформацію, яка дозволяє розкрити корупційні правопорушення третіх осіб. Звичайно, що таку інформацію може надати не лише заявник, а й свідок у кримінальному провадженні. Так, особи, які володіють даними про корупційні кримінальні правопорушення, які вже розслідуються, заслуговують державного захисту та стимулювання не менше, ніж ті, хто вперше повідомляють про корупцію [9, с. 129].

На критичну оцінку заслуговує й задекларований комплекс заходів захисту викривача, який за умов чіткої визначеності щодо ознак викривача та поданої ним інформації, його процесуального статусу та існування відповідальності за неправдиве повідо- млення, навпаки, міг би слугувати доцільним та достатнім комплексом гарантій для особи, яка добросовісно повідомила про достовірно відому їй інформацію про порушення законодавства. Зазначене ж у теперішньому вигляді, 3 високим ступенем імовірності, відкриває можливості реалізації сценаріїв, здійснюваних спеціально уповноваженими органами СРСР 1937 р. Адже, на превеликий жаль, історії вже відомі факти, коли завдяки доносам «небайдужих анонімів» мільйони невинних в інкримінованих їм злочинах позбувалися життя за гратами [15]. Наведене є лише декількома прикладами серед багатьох наявних проблем у цій сфері.

Фахівцями також взагалі висловлюються сумніви щодо життєздатності такого інструменту, як викривач. Серед аргументів складність доведення факту надання чи одержання неправомірної вигоди; щодо виплати викривачу винагороди у вигляді 10 \% від грошового розміру предмета корупційного злочину або від завданого державі збитку після ухвалення обвинувального вироку суду, але не більше ніж 3 тис. мінімальних заробітних плат: по-перше, саме суд встановлює розмір винагороди, яка підлягає виплаті викривачу, та конкретні критерії, які при цьому повинен також визначити суд; по-друге, межа виплати все ж таки існує - 3 тис. мінімальних заробітних плат; по-третє, грошовий розмір предмета злочину або завдані державі збитки від такого злочину в 5 тис. і більше разів повинні перевищувати розмір прожиткового мінімуму для працездатних осіб [16].

Також важливо відзначити, що проблеми функціонування інституту викривачів корупції мають не лише юридичний (матеріальний та процесуальний) характер, а й, зокрема, соціально-культурний, психологічний тощо.

Наприклад, чекати змін у сфері запобігання корупції можна лише після того, як громадяни усвідомлять, що можуть насправді впливати на стан корупції, та повідомлятимуть про корупційні дії чиновників до антикорупційних органів. Важливо, що Законом України «Про запобігання корупції» закріплено обов'язок державних органів, органів влади Автономної Республіки Крим та органів місцевого самоврядування забезпечувати «внутрішні канали» для повідомлення їхніми працівниками про порушення вимог Закону України «Про запобігання корупції» іншою особою (спеціальні телефонні лінії, веб-сайти, засоби електронного зв'язку) [17]. Проте для того, аби громадськість усвідомила свою роль і значення у запобіганні та протидії корупції через інститут викривачів, держава має сама всебічно сприяти 
цьому, наприклад, проводити рекламні кампанії (через телебачення, радіомовлення, інтернет-простір), заходи в освітніх закладах всіх рівнів, пояснюючи важливість інформації від викривачів для відповідних органів державної влади.

\section{Висновки}

Таким чином, підводячи підсумки, варто зазначити таке.

1. Питання запобігання корупції та іiї подолання в Україні є таким же актуальним, як і на початку становлення країни як незалежної держави. Корупція є складним, багатовекторним явищем і таким, що охопило всі сфери діяльності органів державної влади, різних державних установ та підприємств, органів місцевого самоврядування. Незважаючи на створення цілісної системи спеціалізованих органів для реалізації антикорупційної функції (Національне антикорупційне бюро, Національне агентство з питань запобігання корупції, Спеціалізована антикорупційна прокуратура, Вищий антикорупційний суд), що відповідає сучасним міжнародним стандартам, недоліки у їхній діяльності та загалом у реалізації антикорупційної політики продовжують виступати суттевим чинником відсутності розвитку економіки України, що своєю чергою впливає на функціонування інших систем суспільства, відсутність бажання в іноземних інвесторів залучати інвестиції в Україну, визнання України рівнозначним суб'єктом на міжнародній арені.

2. Відсутність бажаного результату після створення низки антикорупційних органів в Україні надала ще більш чітке розуміння необхідності активного залучення приватного сектору. Тому сучасна антикорупційна інфраструктура включає як суб'єктів державного характеру, так і різних суб'єктів з неурядового сектору. Проведений аналіз вітчизняної антикорупційної політики та зарубіжний досвід (США, Канада, Велика Британія, Нова Зеландія, Австралія, Японія, Румунія та ін.) свідчать, що саме залучення до антикорупційної діяльності приватних осіб є найбільш ефективним інструментом у боротьбі 3 корупцією. Злагоджена та системна антикорупційна діяльність всіх суб'єктів спроможна вивести Україну зі складного економічного становища.

3. Сучасний розвиток антикорупційного законодавства має багато позитивних здобутків, але разом із тим залишається низка проблемних питань, які мають як юридичний зміст, так і соціально-культурний. Щодо юридичних механізмів, то існує потреба у подальшому розвитку законодавства щодо захисту прав та інтересів викривачів; захист прав викривачів сьогодні $\epsilon$ невіддільним компонентом протидії корупції як негативному суспільному явищу й, до речі, необхідним та перспективним напрямом досліджень вітчизняних вчених; соціально-культурний чинник розвитку інституту викривачів також вимагає активних дій від держави та громадських організацій відповідного напряму діяльності, наприклад, через проведення просвітницьких заходів: флешмобів рекламних кампаній, заходів в освітніх установах різних рівнів щодо порядку та каналів подання повідомлень щодо корупції. Однак головним вектором змін у цьому напрямі має стати усвідомленість громадян щодо їхнього можливого впливу на корупційне становище у державі; складність вирішення цього завдання полягає в тому, що українське суспільство здебільшого негативно ставиться до осіб, які здійснюють «донос» інформації до відповідних органів державної влади. Формування поваги у суспільстві до викривачів корупції та розуміння їх неоціненної ролі для розвитку Української держави, особливо економіки, є провідним напрямом просвітницької та іншої діяльності з метою інтегрування такого ставлення до національної правової культури громадян.

\section{Список використаних джерел:}

1. Косиця О. О. Адміністративно-правовий механізм забезпечення прав викривачів в Україні : автореф. дис. ... д-ра юрид. наук: 12.00 .07 . Суми, 2019. 36 с.

2. Косиця О. О. Інститут викривачів в Україні: адміністративно-правовий аспект : монографія. Київ: Людмила, 2019. 355 с.

3. Naziru S., Zaleha O. Corruption Typology: A Review of Literature. Chinese Business Review. Feb. 2017. Vol. 16, №. 2. P. 102-108.

4. Nalyvaiko L., Marhenko O., Ilkov V. The phenomenon of corruption conceptualization: international practices and Ukrainian experience. Economic Annals-XXI. 2018. № 127 (7-8). P. 32-37.

5. Аналітичний звіт про виконання Антикорупційної стратегії на 2014-2017 роки та Державної програми щодо реалізації засад Антикорупційної стратегіï. URL: https://old.nazk.gov.ua/sites/ default/files/docs/2017/міжнародні\%20програми/ Аналіз\%20виконання\%20антикорупційної\%20 стратегіï\%202014-2017\%20роки\%20(1).pdf (дата звернення: 12.12.2020).

6. Спеціалізовані інституції 3 боротьби проти корупції: огляд моделей. URL: https://old nazk.gov.ua/sites/default/files/docs/nazk files/ антикордослідження/22.pdf (дата звернення: 12.12.2020).

7. Корупція в Україні: розуміння, сприйняття, поширеність. Звіт за результатами опитування підприємців, експертів та населення в цілому / кол. авт. Київ: Ваіте, 2018. 42 с. 
8. Індекс сприйняття корупції (CPI): динаміка останніх 5 років. URL: https://nabu.gov.ua/ open-office/biblio/sociologiya/indeks-spriynyattyakorupciyi-sri-dinamika-ostannih-5-rokiv (дата звернення: 12.12.2020).

9. Татаренко Г. В., Мезеря О. А., Татаренко I. В. Реформа інституту викривачів корупції в Україні: довгоочікувані зміни чи імітація прогресу. Актуальні проблеми права: теорія практика. 2020. № 1. С. 127-142.

10. Проект Закону про засади державної антикорупційної політики на 2020-2024 роки. URL: http://w1.c1.rada.gov.ua/pls/zweb2/webproc4_1? pf3511=70007 (дата звернення: 02.12.2020).

11. Угода про Асоціацію між Україною, 3 однієї сторони, та Європейським Союзом, Європейським співтовариством 3 атомної енергії і їхніми державами-членами, 3 іншої сторони. Офімійний вісник України. 2014. № 75. Т. 1. C. 83. Ст. 2125.

12. Василинчук В. І., Грибовський О. В. Міжнародні принципи захисту осіб, які надають допомогу із запобігання та протидії корупції. Науковий вісник Національної академії внутрішніх справ. 2014. № 4. C. 223-232. URL: http//elar.naiau,kiev. ua/bitstream/123456789/677/1/21.pdf (дата звернення: 02.12.2020).
13. Нестеренко О. Правовий захист викривальників (whistleblowers): теоретичні аспекти та конституційна необхідність. Право Украӥни. 2014. № 12. С. 104-111.

14. Чудик Н. О., Антоник Є. А. Інститут викривачів у запобіганні та протидії корупції в Україні. Актуальні проблеми правознавства. 2019. Вип. 4. С. 141-146.

15. Інститут «викривачів корупції» в сучасних умовах або «благими намірами вимощена дорога до пекла». URL: https://uifuture. org/publications/25056-instytut-vykryvachivkoruptsii/ (дата звернення: 11.12.2020).

16. Викривачі корупції: де є ризики та як зробити цей інструмент життєздатним? Юридична Газета online. 28 квітня 2020. URL: https:// yur-gazeta.com/publications/practice/kriminalnepravo-ta-proces/vikrivachi-korupciyi-de-e-rizikita-yak-zrobiti-cey-instrument-zhittezdatnim.html (дата звернення: 11.12.2020).

17. Інститут викривачів - важливий запобіжник виникнення та поширення корупції в суспільстві. URL: http://ivaadm.gov.ua/pravovadopomoha/item/12726-instytut-vykryvachivvazhlyvyi-zapobizhnyk - vynyknennia-taposhyrennia-koruptsii-v-suspilstvi (дата звернення: 12.12.2020)

Yevhen Kobko. The institute of whistleblowers as a tool to prevent and combat corruption in Ukraine

The article examines modern tools for preventing and combating corruption. It is emphasised that corruption is a complex, multi-vector phenomenon and one that has covered all spheres of state and local selfgovernment. Given the current Ukrainian realities, it is impossible to fully and thoroughly investigate the issue of corruption without studying the institution of whistleblowers. It is highlighted that for many countries of the world the presence of the institution of whistleblowers is one of the effective means of detecting and overcoming corruption and promising ways of democratic development of society. After all, it is through this form of interaction that it is possible to involve the public in anti-corruption policy and effectively cooperate with civil society, thus ensuring the progressive development of an open modern state.

It is noted that the lack of the desired result after the establishment of a number of anti-corruption bodies in Ukraine has provided an even clearer understanding of the need for active involvement of the private sector. Therefore, the modern anti-corruption infrastructure in Ukraine includes various entities of both state and various entities from the non-governmental sector. Foreign experience shows that the involvement of individuals in anti-corruption activities is the most effective tool in the fight against corruption.

It is emphasised that the current development of anti-corruption legislation has many positive achievements, but at the same time there are a number of problematic issues that have both legal and sociocultural content. Regarding legal mechanisms, there is a need for further development of legislation to protect the rights and interests of whistleblowers; the socio-cultural factor in the development of the institution of whistleblowers also requires active action by the state and public organizations in the relevant field of activity. The main vector of changes in this direction should be the awareness of citizens about their possible impact on the state of corruption in the country.

Key words: corruption, whistleblower, anti-corruption policy, anti-corruption legislation, anticorruption infrastructure. 